\title{
Community-based groundwater and ecosystem restoration in semi-arid north Rajasthan (1): socio-economic progress and lessons for groundwater- dependent areas
}

Dr Mark Everard, University of the West of England (UWE), Coldharbour Lane, Frenchay Campus, Bristol BS16 1QY, UK (mark.everard@uwe.ac.uk, +44-(0)-7747120019)

\begin{abstract}
Groundwater is a vital resource in arid and semi-arid regions, increasingly relied upon for year-round access, though lack of both study and regulation contribute to unsustainable pressures potentially contributing to a negative spiral of ecological, social and economic decline. Using field visits, interviews with locals and experts, and literature reviews, we explored a successful programme of community-based groundwater recharge in three adjacent catchments (the Arvari, Sarsa and Baghani) in semi-arid north Rajasthan, India, led by the NGO Tarun Bharat Sangh (TBS) in order to determine how successes were achieved and could be replicated. TBS-led initiatives rebuilt traditional village governance structures and participation in community-designed and maintained water harvesting structures (WHSs), which were efficient both economically and in technical design using indigenous knowledge. Enhanced seasonal groundwater recharge enabled by WHSs regenerated aquatic, farmed and natural ecosystems, underpinning a positive cycle of interdependent social and economic regeneration. Locally appropriate, integrated social and technical solutions maintaining this positive cycle have increased the quality of ecosystems and the wellbeing of local people. We used the STEEP (Social, Technological, Economic, Environmental, Political) framework to stratify outcomes, exploring principles underpinning successful local and catchment-scale regeneration and drawing out lessons transferrable to similarly water-stressed regions.
\end{abstract}

\section{Keywords}

Rajasthan, semi-arid, groundwater, community, recharge, governance

\section{Introduction}

Groundwater is a vital resource in arid and semi-arid regions where surface water is scarce and subject to high evapotranspirative losses. Human dependence on groundwater has increased globally, with groundwater suppling over half the world's fresh water withdrawals including up to $20 \%$ of irrigated agriculture, $75-90 \%$ of drinking water in some European countries, and $95 \%$ of public supply to rural US populations (Aureli and Ganoulis, 2003; United Nations, 2003; Eckstein and Eckstein, 2005; Mateljan, 2007). However, the 'hidden' nature of groundwater subjects it to administrative and scholarly neglect, and vulnerability to unwitting overexploitation (Downing, 2002; Glennon, 2002; Staddon, 2010). Whilst underexploited in some localities, groundwater extractions elsewhere exceed natural 
replenishment; lack of appropriate monitoring of abstraction, recharge rates and resource status contribute to a mounting groundwater crisis in many parts of the world (Famiglietti, 2014). Global transition towards centrally mandated, neoliberalised systems complicates examination of successful local water governance arrangements (Budds and McGranahan 2003; Staddon, 2010).

This paper addresses community-led groundwater recharge led by the NGO Tarun Bharat Sangh (TBS) in a semi-arid region of Rajasthan state, India. This region had previously experienced a cycle of groundwater depletion and linked ecological and socio-economic decline, TBS-led initiatives since the mid-1980s contributing to reversing this cycle. We draw upon pertinent issues of local governance of groundwater management from the extensive literature on groundwater resource exploitation in arid and semi-arid regions. We also address relationships between competing resource managers, particularly centralised state/national government versus village- and catchment-scale councils supported by TBS, to explore how the system evolved and why the Indian state is beginning to accept it as a legitimate form of integrated water management.

Our research organised knowledge deduced from the literature and field visits around the STEEP (Social, Technological, Economic, Environmental, Political) framework to test the hypothesis that multiple and complex factors are entailed in restoring community-based groundwater recharge in target catchments, and further to deduce key lessons about success criteria that are potentially transferrable to other arid and semi-arid, groundwater-dependent regions. STEEP was developed initially to assess global change issues (Morrison and Wilson, 1996). However, it has been applied to analyse systemic relationships in different domains of human activity in meeting sustainability goals (Steward and Kuska, 2011), including deployment of appropriate technology and associated governance systems in management of water, ecosystem service flows and dependent development issues in South Africa and Europe (Everard and Colvin unpublished; Everard et al. 2012; Everard 2013). Aside from structuring the analysis of interconnected factors, use of the STEEP framework also helps overcome acknowledged subjectivity due to data limitations in wetland assessment and valuation (Woodward and Wui, 2001) through integration of objective and subjective assessments (Aretano et al., 2013).

\section{Methods}

Methods comprise three sub-sections: (2.1) review of relevant aspects of groundwater use and dependence in Rajasthan, India; (2.2) overview of case study regenerated river basins; and (2.3) review of pertinent aspects of the Tarun Bharat Sangh programme of water management in Alwar District.

\subsection{Groundwater use and dependence in Rajasthan, India}

Environmental water resources support multiple indirect ecosystem services and associated societal benefits in addition to direct uses (Everard, 2013). Groundwater supports over $85 \%$ of India's rural domestic water requirements, $50 \%$ of urban and industrial water needs and nearly $55 \%$ of irrigation demand (Government of India, 
2007). 92\% of India's extractions of groundwater are for irrigation (Central Ground Water Board, 2006). Groundwater-irrigated land area increased by nearly $105 \%$ in the two decades to 2009 (Jha and Sinha, 2009). Across India, more than 22 million operational wells support poverty reduction in rural India and the wider Indian economy (Wani et al., 2009), with the number of mechanised wells increasing from less than one million to more than 19 million during the last four decades of the twentieth century (Jha and Sinha, 2009). Small and marginal farmers comprise 20\% of the total agricultural area yet $38 \%$ of the net area irrigated by wells, with $35 \%$ of tube wells fitted with electric pump sets (Jha and Sinha, 2009). Globally, the contribution of small and local-scale farming to food security is significantly underappreciated as approximately $\mathbf{5 0 0}$ million smallholder farmers, many struggling in the face of climate change and economic uncertainty, feed one third of the world's population (Birch, 2012).

Rajasthan is India's largest state, occupying $10 \%$ of national land area and encompassing significant regions of desert, mountain, city, wetland and some of the Gangetic Plain in northern India (Figure 1). However, it contains only $1 \%$ of the nation's surface water resources. Consequently, $60 \%$ of Rajasthan is arid and $40 \%$ semi-arid, $90 \%$ of annual rainfall occurring in the monsoon months of July to September (Jayanti, 2009). Agricultural activities in Rajasthan consequently rely heavily on groundwater. However, groundwater overexploitation has triggered mass movements of people from Rajasthan's semi-arid villages towards better watered regions or urban centres offering greater material life prospects (Hills, 1966). Crop and animal husbandry remain important components of Rajasthan's economy yet also contribute to water stress (Hills, 1966). The Government of India classified groundwater zones as 'white', 'grey' or 'dark', depending on degree of exploitation; more than $50 \%$ of aquifers were declared 'dark' (overexploited) across Rajasthan (Rathore, 2003).

Figure 1: Location of the Arvari, Sarsa and Baghani catchments in north Rajasthan 


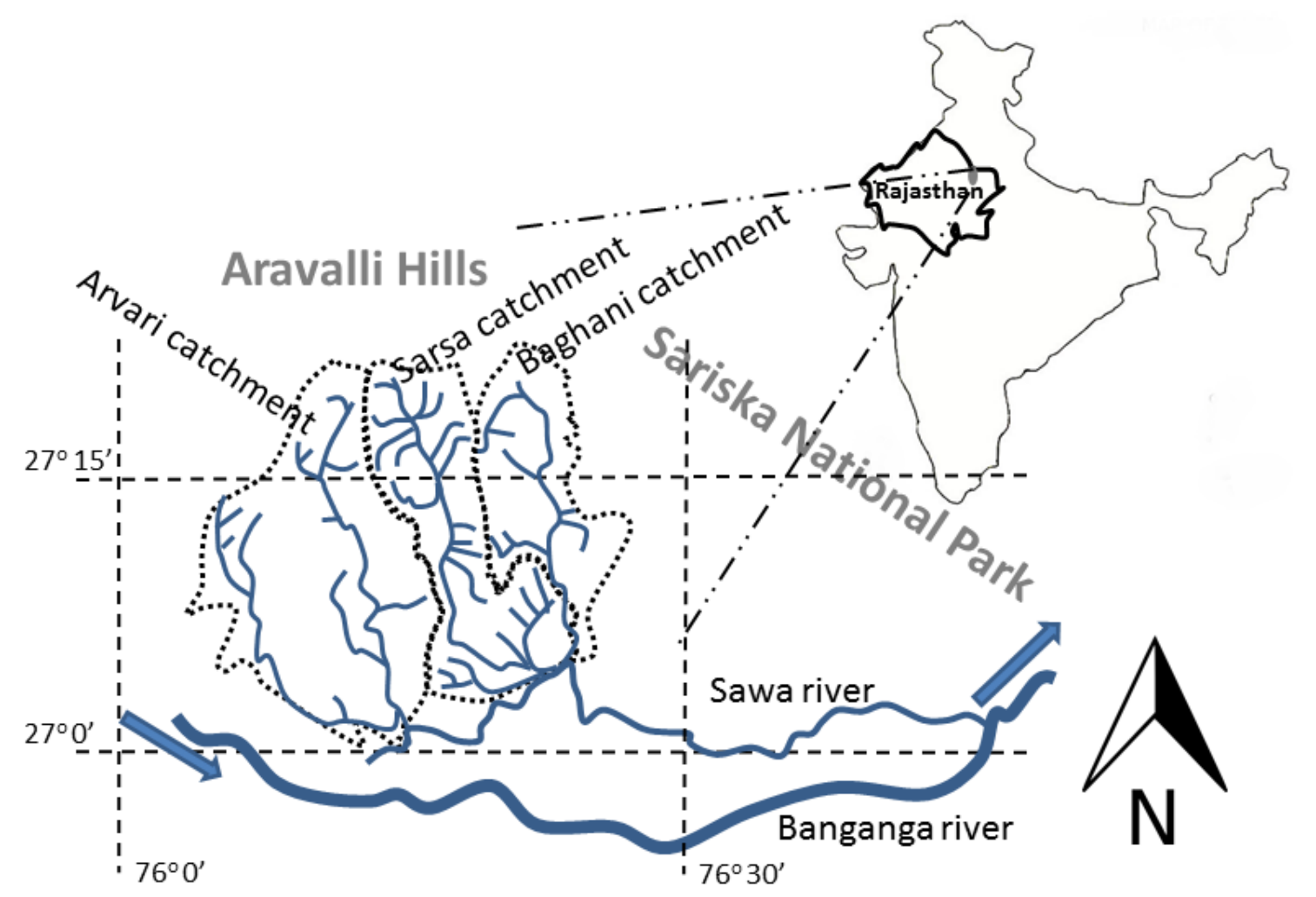

India has a long tradition of water harvesting adapted to climatic conditions, historical records revealing reservoirs and dams in Rajasthan from the 1660s through to the pre-colonial period serving cultivable areas through canal irrigation and groundwater percolation (Gupta, 2011). Diverse water harvesting structures (WHSs, also known as rainwater harvesting structures, $\mathrm{RWHs}$ ) formerly proliferated in India, ranging from massive to diverse types of small local structures adapted to local topography and agro-ecology (Gupta, 2011). British chroniclers in 1856 found a flourishing tank culture for water storage in India, including across the arid lands of Rajputana, now largely Rajasthan (Sharma et al., 2013). WHSs have a range of local names, but are commonly referred to in Rajasthan as 'johadi' (singular: 'johad'); johadi intercept or slow overland flows, particularly during monsoon rainfall, promoting groundwater recharge with some also storing surface water for year-round availability (Subramaniam, 2014). This diversity of traditional WHSs reflects centuries of innovation and indigenous knowledge, adapting livelihoods to local conditions (Agarwal and Narain,1997) and representing societal and cultural responses to prolonged local aridity, matching palaeoclimatological evidence for climate change during the Holocene with archaeological and historical records.

However, much indigenous knowledge about and participation in WHSs in India has been lost in modern times (Mishra, 1997), particularly driven by centralisation of water management responsibilities resulting in unsustainable livelihoods, population dislocation, cultural separation, habitation abandonment and societal collapse in some semi-arid regions (Pandey et al., 2003). Mishra (1995) highlights how modern education overlooks the significant contributions of WHSs, accelerating loss of knowledge, social structures, physical infrastructure and flows of ecosystem services precipitating socio-economic decline of the kind recorded in late-Colonial and postindependence Rajasthan. 
Failing groundwater resources, driven by the still largely unregulated pump irrigation revolution since the 1970s, poses serious socio-ecological threats across much of South Asia (Downing, 2002; Postel, 1999; Vaidyanathan, 1996) and a major threat to food security in India (Kumar, 2003). A quarter of India's food harvest is at risk if groundwater is not managed properly (Seckler et al., 1999). 10\% of global food production depends on overdraft of groundwater, with $50 \%$ of this area in Western India (Postel, 1999). Declining groundwater levels could reduce India's harvest by $25 \%$ or more (Singh and Singh, 2002), with associated distributional impacts as the costs of deepening wells often excludes small and poorer farmers from access to water before wealthy farmers and other affluent users (Moench, 1994).

However, a wide range of indigenous management practices from Eurasia to Africa and the Americas demonstrate that groundwater can respond to positive management, supporting multiple benefits for dependent communities (Pearce, 2004; Everard, 2013). Wani et al. (2009) report significant groundwater rises where community-based participatory methods were developed at benchmark sites in several Indian states/provinces and in Thailand, Vietnam and China. These community empowerment initiatives, bringing together institutions from scientific, non-government, government and farming sectors, restored groundwater levels, improved productivity by up to $250 \%$, reversed degradation of natural resources, and substantially improved the livelihoods of poor people in 368 experimental watersheds across Asia (Wani and Ramakrishna, 2005; Wani et al., 2006). In experimental watersheds in India, including the Bundi watershed in Rajasthan, water levels in wells close to community-constructed and maintained WHSs improved groundwater yield both quantitatively and in terms of duration compared to more remote wells (Wani et al., 2009). Groundwater level in the Bundi watershed rose by $5.7 \mathrm{~m}$, with a corresponding 66\% increase in irrigated area (Wani et al., 2003).

Locally effective governance is necessary to coordinate effort to restore groundwater levels, but also to prevent gains being offset by increasing numbers of boreholes. Integrated watershed management emphasising in-situ, farm-scale conservation of rainwater recognises the interdependence of water resource stewardship with food production and human security at local scales (Wani et al., 2009).

\subsection{Background and study of selected regenerated river basins}

This paper's focal case study is the predominantly rural Arvari (or Arwari), Sarsa and Baghani catchments, lying mostly in Alwar district, north-eastern Rajasthan (Figure 1). Their headwaters rise from the Aravalli Hills on a geology of folded and fractured conglomerate, grit and arkosic quartzite rock through which groundwater flows (Rathore, 2003). The Arvari catchment (area of $476 \mathrm{~km}^{2}$ ) is semi-arid, comprising 46 micro-watersheds with a covering sand sheet on flatter land downstream that protects the aquifer, also comprising soils that are fertile but which lack water (Rathore, 2003; Glendenning and Vervoort, 2010). The Sarsa and Baghani catchments share the Arvari's general character and hydrogeological conditions.

Long-term average rainfall for Alwar district is $657.3 \mathrm{~mm}$, though rainfall is unevenly distributed spatially and across the year, determining agricultural potential. The 
2011 Indian census recorded a population of 3,671,999 for Alwar District, a 23\% increase since the 2001 census (2,992,592 people).

http://www.census2011.co.in/census/district/429-alwar.html). Agricultural production in Alwar district is significant within Rajasthan, with irrigation from wells and tube wells supporting about $83 \%$ of the 507,171 hectares of cultivated area. A considerable proportion of the irrigated area is double-cropped. An estimated 35,470 electric motors and 66,502 diesel pump sets are used for irrigation purposes (http://www.districtalwar.com/index.aspx, accessed $11^{\text {th }}$ October 2015). Alwar's cultivated land produces, in declining area extent, Bajra (pearl millet), jowar (sorghum), guar (cluster bean), maize, arhar (pigeon pea), cotton, ground nut, rice and pulses. Rough grazing is not intensive due to the predominantly vegetarian local diet.

The valleys of the Aravalli Hills were well-vegetated up to mid-1930s, after which timber rights were sold to private interests and, within ten years, ecological decline and associated increased incidences of seasonal flooding and drought ensured (Rathore, 2003). Sale of forest rights and sub-lease of land for mining were reportedly instigated by a prince anticipating that post-Independence India would remove his primacy (http://tarunbharatsangh.in, accessed $11^{\text {th }}$ October 2015). Around the same period, administrative reforms passed water management responsibilities from local to state and national government.

Removal of water management responsibilities from local control led to a shift in perception of the value of water, disengagement of local people with management of assets and responsibility for supply-side management, and hence widespread abandonment and consequent degradation of community water management structures (Rathore, 2003). Local emphasis shifted to greater mechanical efficiency in resource exploitation, reducing dependence on bullock-operated wells in favour of energisation (diesel and electric pumps) for extraction from ever-deeper wells and tube wells. Government data reported by Rathore (2003) records that groundwater extraction in Alwar district was $66 \%$ of the available resource in $1984,110 \%$ in 1988 , $108 \%$ in $1989,119 \%$ in $1995,100 \%$ in 1998 and $118 \%$ in 2001 , with groundwater levels receding to below 100 metres from surface level in many places across Rajasthan substantially reducing land viable for cropping. Substantial depletion of groundwater produced adverse ecological, social and economic consequences. Forest cover declined to between 3\% (Subramaniam, 2014) and 7\% (Singh, 2009) of land area, with only $28.6 \%$ of the notified forest area on the Aravalli Hills showing up as green in remote sensing in 1984 (Down to Earth, 1999a). Continued unsustainable overexploitation of groundwater contributed to a cycle of linked ecological and social degeneration generating hydrological poverty, manifesting through the declining viability of stock and crop production and fuel wood availability, driving migration of people from villages to cities across rural Rajasthan (Rathore, 2005). Rathore (2003) stated that "Migration to urban and peri-urban areas is symptomatic of the deepening crisis in the farm and rural sectors", substantially driven by declining access to water and associated ecosystem services.

\subsection{The Tarun Bharat Sangh programme of water management in Alwar District}


Tarun Bharat Sangh (TBS) is an activist organisation centred in Bheekampura, Alwar district. TBS was established in 1985 by Rajendra Singh against a backdrop of rural depopulation, economic and ecological decline initially following colonial exploitation and then, after 1947, successive waves of state-brokered 'accumulation by dispossession' (Harvey, 2003) with respect to water and land resources (Subramaniam, 2014). TBS efforts focus on local and practical measures, defined as 'Community self-reliance through natural resource conservation' embedding the Gandhian ethos of Jal Swara including participation, equity and decentralisation of water management recognising the vitality of soil, water, ecology and human livelihoods as interdependent (Jayanti, 2009). (Gandhi never used the words 'environment protection'; his caution against unrestricted industrialism and materialism relate to living within the carrying capacity of natural resources interpreted within a local context: Gandhi, 1947).

The TBS programme has attracted national and international recognition for contributing to the reversal of cycles of aridification, ecosystem degradation and consequent human impoverishment and depopulation. This review drew from field visits, interviews and published sources (including 'grey literature' not necessarily readily accessible to researchers and practitioners). Interviews took the form of semi-structured conversations relating the history, management, consequences and reasons for involvement in community water management, opportunistically with TBS staff (Rajendra Singh, Abhinav Agrawal, Kanhaiya Lal, Gopal Singh, Maulik Sisodia, Suresh Raikwar), village elders and decision-makers (particularly Rudhmalmena, the headman of Harmeerpur village) and ad hoc discussions with local people encountered near water-harvesting structures with TBS staff or an independent driver (Rakesh Vaish) acting as translators during two field visits in summer (the driest part of the year) during March 2013 and March 2015. Catchment characteristics, the history, key features and current uses, and adjacent land uses of eleven water management structures of different types and in different locations in the Arvari, Sarsa and Baghani were surveyed during field visits. Latitude and longitude were deduced from Google Maps, altitudes were derived subsequently using www.mapcoordinates.net/ and water body areas were assessed using the http://www.daftlogic.com/projects-google-maps-area-calculator-tool.htm planimeter tool. Dates of Google Maps images were not provided, so area data is purely illustrative given the seasonal variability of water bodies. Comparison was made with adjacent catchments where WHSs had largely not been maintained or regenerated. The catchment visit was augmented by exchanges with numerous experts in local ecosystem management and in international wetland and catchment management.

The initial educational emphasis of TBS changed in 1985 when a village elder told Singh that the primary local issue was lack of water, not education (Jayanti, 2009; Singh, pers.comm.). Many formerly perennial local rivers by then flowed only during monsoon rains, and agricultural land productivity had declined to an historic and declining low. Singh and colleagues took advice from a lower-caste older lady to restore or create small, localised WHSs to recharge groundwater, initially setting about building a small johad to retain monsoon run-off enabling it to recharge groundwater. This first TBS-initiated water capture structure was built in 1985 in collaboration with villagers of Gopalpura, a risky undertaking with uncertain results. However, the Gopalpura johad functioned as anticipated, restoring soil moisture and 
ecology for improved food production, rejuvenating local grazing and other vegetation, and re-establishing some vitality to the river (Singh, 2009). This generated growing interest in constructing WHSs from adjacent parched, depopulating villages, to which TBS activities expanded progressively as the NGO attracted funds significantly from international donor sources.

Demand-led construction of hundreds of johadi followed, TBS contributing typically $30-70 \%$ of costs building on investment by beneficiaries in host villages. Significant catchment-scale outcomes ensued, leading Singh to remark that "We never realised that we were recharging a river. Our effort was just to catch and allow water to percolate underground" (Down to Earth, 1999b). Pangare (2003) estimated that TBS received around 1,500 requests for building structures annually, but could only build around 300.

WHS designs promoted by TBS are informed by local needs, topography, microcatchment area, knowledge and budgets, but based around three generic designs: concave earth-banked johadi in flatter topography; flat check dams (anicuts) on wider micro-catchments with low slope; and convex dams bulging upstream to intercept water on higher slopes. The primary purpose of WHSs is promotion of groundwater recharge, though some have additional capacity to store surface water throughout the dry season for livestock watering and other uses. Tree-planting and regeneration also restores catchment hydrology, both reforesting denuded hillsides and providing shading on some johadi to reduce evaporation. Anicuts built to attenuate water flows across flat valleys can retain significant bodies of surface water during monsoon rains that moistens and carries nutrients into soils subsequently cropped throughout the dry season for mustard, channa (chick peas), bindi (a vegetable also known as okra or lady's fingers) and wheat, and percolates to recharge wells (personal observation; Singh, pers. comm.; Kanhaiya, pers comm., Rudhmalmena, pers.comm.)

Construction and management of WHSs resurrects traditional technologies and knowledge and the social infrastructure necessary to operate them. The importance of social infrastructure cannot be overstated. Therefore, TBS only responds to demand from villages, the process of building and maintaining johadi dependent upon resurrection of traditional village institutions (Kumar and Kandpal, 2003), prominently including 'Gram Sabha': traditional village decision-making bodies with interests in deliberation and decision-making about water management (Jayanti, 2009). Whilst some Gram Sabha became dormant after johad construction, many remained active where support from TBS continued, building social capital and progressing to tackle related issues including protecting forests, building schools and other developmental works (Kumar and Kandpal, 2003), and zoning and regulating land uses to avoid ecological and socio-economic degradation (Singh, pers.comm.) By 2010, TBS was working with more than 700 villages in Rajasthan.

Reported numbers of completed johadi and related works vary from 200 (Subramaniam, 2014) to 366 (Glendenning and Vervoort, 2010), 375 Jayanti (2009), 650 (Down to Earth, 1999a) and 3,200 (Kumar and Kandpal, 2003). Near-global recognition of successes in regenerating linked socio-environmental systems across a range of sub-catchments - including restoration of perennial surface water to catchments formerly dry outside of monsoon rains, regeneration of farm productivity 
and reversal of village abandonment - has the media commonly to refer to Rajendra Singh, the TBS founder, as the 'Waterman' or 'Rivermaker'.

Responding only to demand from villages potentially fragments action across landscapes (Kumar and Kandpal, 2003). To achieve a more integrated approach, TBS promoted formation from 1998 of an Arwari Water Parliament, or Pad Yatra, which meets twice yearly to determine water sharing and management issues across the Arvari catchment including dispute resolution and activities such as reforestation (Rathore, 2003; Jayanti, 2009). In 1998, TBS also launched 'Rashtriya Jal Biradari' (RJB: 'National Water brotherhood'), comprising individuals from all walks of life farmer groups, social groups, voluntary organizations, NGOs, research institutions, social scientists and water experts - concerned about water conservation, forest and soil management, promotion of water conservation work, and re-establishment of community water rights through awareness programs and Jal Sammelans (conferences) aimed at developing people-oriented national and state water policy (http://tarunbharatsangh.in/rashtriya-jal-biradari-rib/, accessed $11^{\text {th }}$ October 2015).

Experience in regenerated catchments has not been uniform or entirely free of challenge, particularly from state and central government, whose perspectives on water management differ and whose departments wield more institutional and legal power than TBS, village councils and Water Parliaments.

\section{Results}

The Results section comprises two parts: (3.1) characteristics of surveyed water management structures, and (3.2) outcomes of water and ecosystem service restoration activities stratified using the STEEP framework.

\subsection{Characteristics of surveyed water management structures}

Physical and historical characteristics of WHSs and their associated bodies are described in Table 1. Aquatic taxa - fish, amphibian, odonata, water birds and obligate hydrophytes (described with associated non-marketed ecosystem services by Everard, in preparation) - were observed nine of the eleven water bodies, demonstrating permanence in a landscape formerly lacking in surface water.

Table 1: Characteristics of WHSs and associated water bodies in the Arvari, Sarsa and Baghani catchments

\begin{tabular}{|l|l|}
\hline \multicolumn{2}{|l|}{ Arvari catchment } \\
\hline JS & $\begin{array}{l}\text { Jabar Sagar }\left(27.207373^{\circ} \mathrm{N}, 76.202331^{\circ} \mathrm{E}, 386 \text { metres altitude, } 1,528 \mathrm{~m}^{2} \text { area) is an anicut on }\right. \\
\text { the Arvari river serving farmland around Harmeerpur. It was one of the earliest installed } \\
\text { with support from TBS, in the latter half of } 1980 \mathrm{~s} \text {. The anicut is the third between the } \\
\text { source of the Arvari and Harmeerpur village, but is one of around } 100 \text { anicuts and johadi } \\
\text { within the catchment and } 49 \text { in the vicinity of the village. Wheat and gram crops, including } \\
\text { a variety of ruderal weeds, are grown right up to the water's edge, which is at its maximum } \\
\text { after monsoon rains in July-September after which water level retreats seasonally. }\end{array}$ \\
\hline KA & $\begin{array}{l}\text { Anicut near Kalid (Kaler) village }\left(27.155427^{\circ} \mathrm{N}, 76.224163^{\circ} \mathrm{E}, 386 \text { metres altitude, } 27,214 \mathrm{~m}^{2}\right. \\
\text { area), downstream of Harmeerpur. The large concrete anicut holds water in the Arvari }\end{array}$ \\
\hline
\end{tabular}




\begin{tabular}{|c|c|}
\hline & $\begin{array}{l}\text { river perennially. It is heavily used for grazing with consequently barren banks and bare } \\
\text { drawdown zones. Fish of different species were clearly visible, and in } 1996 \text { were the } \\
\text { subject of a conflict on Fishing Rights, an interesting issue to encounter in a formerly } \\
\text { aridified and degraded region of the drought-stricken state of Rajasthan (Sinha et al., 2013; } \\
\text { Singh, pers. Comm.). More complete details are provided in the body of this paper, but the } \\
\text { situation revolved around a popular revolt by local people over the control of fish and, by } \\
\text { proxy, water assets regenerated by their own efforts on the award by the Department of } \\
\text { Fisheries, Government of Rajasthan, of fishing rights to a private contractor. }\end{array}$ \\
\hline \multicolumn{2}{|r|}{ Sarsa catchment } \\
\hline $\mathrm{BE}$ & $\begin{array}{l}\text { Beechkharaga }\left(27.249158^{\circ} \mathrm{N}, 76.30568^{\circ} \mathrm{E}, 403 \text { metres altitude), a newly-completed johad }\right. \\
\text { (constructed } 10^{\text {th }} \text { December } 2014 \text { to } 27^{\text {th }} \text { February } 2015 \text {, currently dry with potential area } \\
4,789 \mathrm{~m}^{2} \text { area) where mountain slope drops to valley edge, serving to retain run-off and } \\
\text { recharge aquifer and adjacent open well. The johad is located at the head of a monsoon } \\
\text { nala (drainage channel) near Jaitpur village, upper Sarsa catchment, serving land owned by } \\
9 \text { families. The cost of the scheme was IN₹1.8 lakh, with } 67 \% \text { of costs routed by TBS from } \\
\text { the 'Wells for India' (http://www.wellsforindia.org/) fund and } 33 \% \text { provided by the village. }\end{array}$ \\
\hline GP1 & $\begin{array}{l}\text { Gopalpura }\left(27.268606^{\circ} \mathrm{N}, 76.30753^{\circ} \mathrm{E}, 407 \text { metres altitude, } 882 \mathrm{~m}^{2} \text { area), a johad built in }\right. \\
1985 \text { (the first constructed under the guidance of TBS) in the upper Sarsa catchment. The } \\
\text { johad holds water all year, recharging groundwater and it is also extensively used for stock } \\
\text { watering. There are now } 17 \text { water-harvesting structures in the vicinity of Gopalpura, } \\
\text { serving } 80 \text { families (including the three Chabutra Wala anicuts in the adjacent shallow } \\
\text { valley). }\end{array}$ \\
\hline CW & $\begin{array}{l}\text { Chabutra Wala }\left(27.270369^{\circ} \mathrm{N}, 76.310328^{\circ} \mathrm{E}, 408 \text { metres altitude) is a series of three anicuts }\right. \\
\text { with water level control sluices built across a shallow valley in the upper Sarsa catchment in } \\
1985 \text { by TBS. The anicut surveyed was the most upstream of three anicuts. The three } \\
\text { anicuts retain surface water (field area upstream/north area } 87,969 \mathrm{~m}^{2} \text {, middle area } 22,854 \\
\mathrm{~m}^{2} \text {, downstream/south area } 38,376 \mathrm{~m}^{2} \text { dry at time of survey and on Google Maps image) } \\
\text { until the land is ready for sowing, when water is released downstream by removing } \\
\text { wooden stoppers from holes in the water control sluice. Farmed land upstream of the } \\
\text { anicuts supports crops of wheat, gram, mustard, bindi, brinjal, potato and carrot. Chabutra } \\
\text { Wala is one of } 17 \text { water-harvesting structures in the vicinity of Gopalpura, serving } 80 \\
\text { families. }\end{array}$ \\
\hline GP2 & $\begin{array}{l}\text { Johad by road north of Gopalpura }\left(27.276656^{\circ} \mathrm{N}, 76.302532^{\circ} \mathrm{E}, 411 \text { metres altitude, } 816 \mathrm{~m}^{2}\right. \\
\text { area), a johad on sloping land. The site was observed at dusk, which is not ideal for species } \\
\text { identification. The johad was at the time holding water, but appears to dry down in full } \\
\text { summer once all water has seeped into aquifers or evaporated. There was evidence of } \\
\text { extensive watering of and trampling by animals. }\end{array}$ \\
\hline GK & $\begin{array}{l}\text { Golakabass }\left(27.10133^{\circ} \mathrm{N}, 76.321519^{\circ} \mathrm{E}, 339 \text { metres altitude, } 2,843 \mathrm{~m}^{2} \text { area), a relatively }\right. \\
\text { new check-dam across the Sarsa River, north-west of a road crossing downstream from } \\
\text { which is a broken former dam. The Golakabass check dam spans the river approximately } \\
10 \mathrm{~km} \text { upstream from its confluence with the Sawa River. }\end{array}$ \\
\hline \multicolumn{2}{|r|}{ Baghani catchment } \\
\hline $\mathrm{TI}$ & $\begin{array}{l}\text { Tilda }\left(27.188411^{\circ} \mathrm{N}, 76.414071^{\circ} \mathrm{E}, 329 \text { metres altitude, } 5,488 \mathrm{~m}^{2} \text { area) is a check-dam }\right. \\
\text { constructed across the Tilda River, upstream of its confluence with the Baghani River, } \\
\text { forming a deep, clear-water pool ringed by patera (the local name for Typha angustata). A } \\
\text { temple is located at the head of the impoundment with ghats (steps to the water's edge) } \\
\text { around which fish shoal and swim with bathing children. At the downstream end, women } \\
\text { were washing clothes on the concrete check dam, which we also used as a crossing place. }\end{array}$ \\
\hline TE & $\begin{array}{l}\text { Tehela }\left(27.249588^{\circ} \mathrm{N}, 76.441471^{\circ} \mathrm{E}, 344 \text { metres altitude, } 3,699 \mathrm{~m}^{2} \text { area), a check dam on }\right. \\
\text { the Jalumbragarh river (a tributary of the Baghani system). The Tehela check dam was } \\
\text { installed around } 2000 \text {, near the town of Tehela (population } 5-6,000) \text {. It constitutes a }\end{array}$ \\
\hline
\end{tabular}




\begin{tabular}{|c|c|}
\hline & $\begin{array}{l}\text { shallow impoundment supporting extensive stock watering (water buffalo, sheep, goats) } \\
\text { with wallowing buffalo present, activities which eliminate much marginal vegetation } \\
\text { (except stands of invasive, tall and woody Ipomea carnea growing as an emergent close to } \\
\text { the dam wall) }\end{array}$ \\
\hline MAu & $\begin{array}{l}\text { Mandalwass, upper impoundment }\left(27.277571^{\circ} \mathrm{N}, 76.33273^{\circ} \mathrm{E}, 496 \text { metres altitude, } 73,514\right. \\
\mathrm{m}^{2} \text { area), a large dam on the headwaters of the Baghani River built in } 1993 \text { immediately } \\
\text { above smaller dam on the top of a high mountain ridge. The upper Mandalwass dam is } \\
\text { deep (estimated at } 18-20 \text { feet in low summer weather) with the head heavily grazed, } \\
\text { resulting in little vegetation and dense, greenish (assumed algal) water. This water } \\
\text { condition is exacerbated by high fish stocks (reported but unknown species) in the } \\
\text { impoundment, for which the village people allot contracts to commercial fishermen } \\
\text { providing an annual income used to refurbish the upper and lower Mandalwass dams. The } \\
\text { rocky margin of the impoundment was being used during the survey period for washing } \\
\text { clothes. }\end{array}$ \\
\hline MAI & $\begin{array}{l}\text { Mandalwass, lower impoundment }\left(27.279707^{\circ} \mathrm{N}, 76.333966^{\circ} \mathrm{E}, 496 \text { metres altitude, } 12,896\right. \\
\mathrm{m}^{2} \text { area), the lower of two impoundments repaired at the time the larger, upper dam was } \\
\text { built in } 1993 \text {, the impounded water much shallower, clearer and well-established and } \\
\text { densely vegetated, located on the top of a high mountain ridge. There are some houses } \\
\text { adjacent to the slope to the south of the impoundment, with extensive grazing by buffalo in } \\
\text { the riparian zone. }\end{array}$ \\
\hline
\end{tabular}

Figure 2: Location of WHSs in the Arvari, Sarsa and Baghani catchments. (Site names: JS Jabar Sagar; KA Anicut near Kalid (Kaler) village; BE Beechkharaga; GP1 Gopalpura; CW Chabutra Wala; GP2 Johad by road north of Gopalpura; GK Golakabass; TI Tilda; TE Tehela; MAu Mandalwass; MAI Mandalwass) 


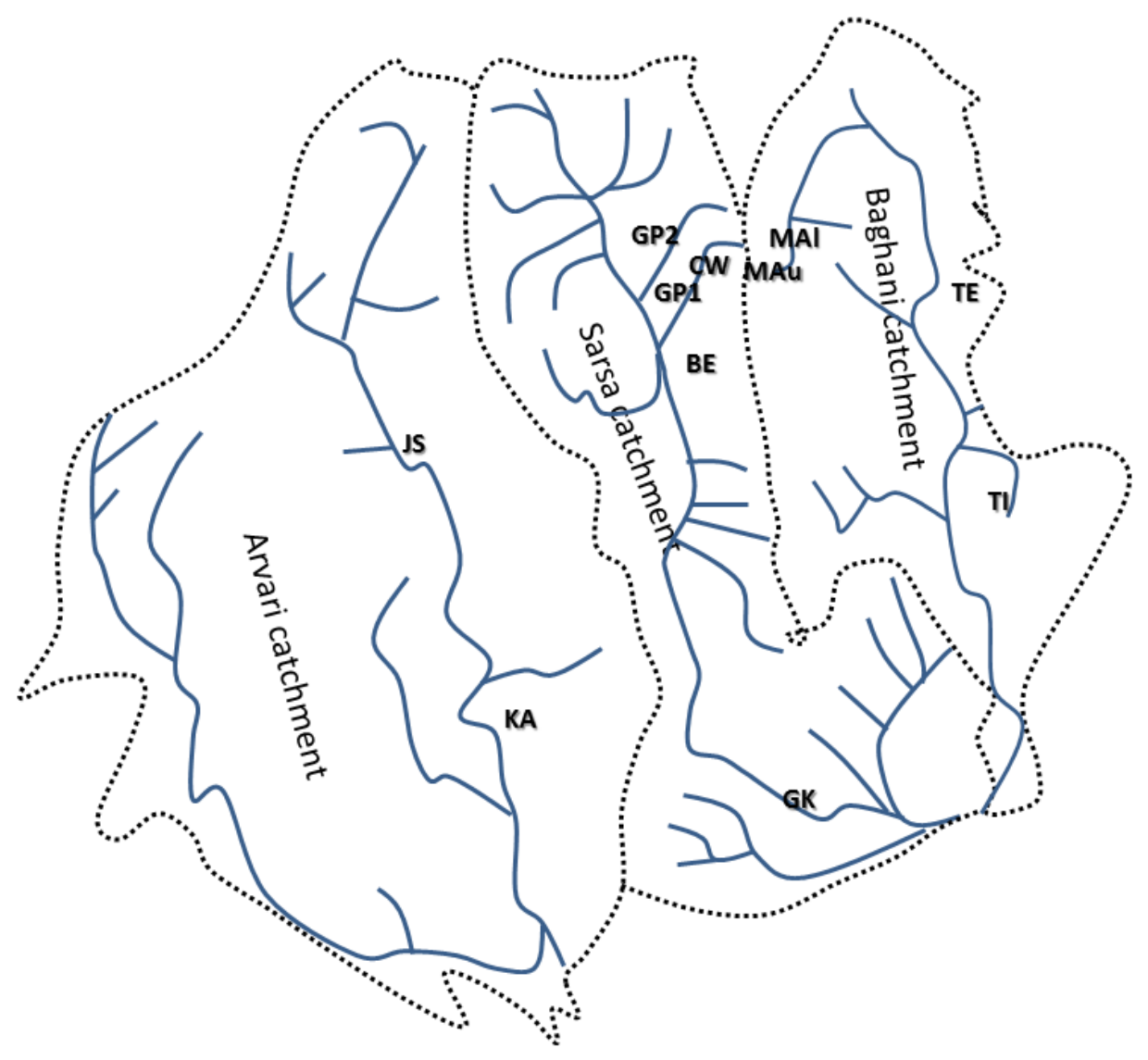

Bias in selection of sampled WHSs is acknowledged in terms of accessibility, guidance from the NGO instrumental in their creation, and limited time for fieldwork. However, the observed subset of WHSs encompassed significant heterogeneity in design, purpose and uses, as well as their resultant ecology and associated societal benefits (addressed by Everard, in preparation). Significant physical differences include:

- Construction linked to location and purposes, ranging from large dams (Mandalwass upper) to low anicuts across shallow valleys (Chabutra Wala) and traditional semi-circular johadi both small (Gopalpura) and large (Beechkharaga);

- Altitude, ranging from headwaters in mountain tops (Mandalwass upper and lower impoundments at 496 metres altitude) to those lower in catchments (Tilda at 329 metres altitude);

- Size, ranging from $73,514 \mathrm{~m}^{2}$ (Mandalwass upper impoundment) to $816 \mathrm{~m}^{2}$ (Gopalpura GP1);

- Longevity, ranging from the first johad at Gopalpura constructed in 1985 through to Beechkharaga, with construction completed in February 2015 and still to fill from monsoon when visited;

- Permanence of water, ranging from those that apparently dry down completely (Johad by road north of Gopalpura) to shallow seasonally wetted valleys above anicuts (Chabutra Wala) to those supporting a rich diversity of obligate aquatic biota (Tilda, Kalid and others); and

- Uses, including washing and bathing (many WHSs), watering, grazing and buffalo wallowing (many including Tehela), management for commercial fishery 
purposes (Mandalwass upper impoundment), and tillage to the water's edge with encroachment of crop and ruderal plants (Jabar Sagar).

All of these factors impose pressures - different densities of marginal poaching and grazing, agriculture to the water's edge, water depth, seasonal draw-down and permanence - that cumulatively shape water body character.

\subsection{Outcomes of water and ecosystem service restoration}

The STEEP framework was used to structure analysis of empirical and literature observations.

\subsubsection{Social outcomes}

Rebuilding of community-based social capital has been central to regeneration of ecosystems and their associated services contributing to a return to prosperity. This is commonly observed in successful groundwater management (Lopez-Gunn, 2012), though it may also be mobilised by institutions pursuing resource privatisation, state disinvestment and other agendas (Birkenholtz, 2009). In 2000, Indian President, KR Narayanan, visited the study site to congratulate local communities for minimising drought consequences through collaboration around WHSs, averting distress migration and indeed seeing farmers and their families returning to their villages (The Hindu, 2000; Kumar and Kandpal, 2003; Singh, 2009 and pers.com.; Rudhmalmena, pers.com.; Sinha et al., 2013).

Challenges remain in resource ownership and capacity to access water, and the established framework of top-down regulation and economic incentives. $58 \%$ of surveyed households in the Arvari catchment preferred community ownership of water resources in forest areas (Rathore, 2003), though $42 \%$ feared capture of community governance and land assets by the rich. This is observed in some villages where larger landholders have resources to drill deeper wells, preferentially exploiting restored groundwater (Subramaniam, 2014). Cochran and Ray (2009) consider equity as central to the success of community-based development efforts, in particular in WHS programmes as evidenced in two Rajasthani communities.

Another significant success of TBS-driven community initiatives is empowerment of women. In 1985, women typically spent 6-7 hours daily searching for water; rising water tables and water access through hand pumps and wells close to housing now reduces this task to 5-6 minutes (Singh, pers. comm.) Freed from the drudgery of traditional roles foraging for water, fodder and fuel, women can devote more time to tackling perceived 'social ills', contributing to health services and education (particularly of girls) and engaging in village-scale decision-making and other productive activities (Kumar and Kandpal, 2003; Jayanti, 2009). TBS has actively empowered women through enabling democratic engagement, education including Ayurvedic (traditional herbal) medicine, and formation of Women Self Help Groups (SHGs) to strengthen the role of women and share learning throughout the catchment (Rathore, 2003). 
Community collaboration and collective governance is central to enabling technological solutions to become sustainable. For his participatory work, Singh was awarded the Asia-wide Ramon Magsaysay Award (Ramon Magsaysay Award Foundation: www.rmaf.org.ph, accessed $11^{\text {th }}$ October 2015) for community leadership in 2001.

\subsubsection{Technological outcomes}

Kumar and Kandpal (2003) reviewed TBS projects cumulatively representing investment of IN₹16.2 million (Indian Rupees: approximately \$US 4.7 million) over the preceding decade. 3,200 Johadi had been built with funding from various sources, the Swedish International Development Cooperation Agency (SIDA) contributing between $9 \%$ and $77 \%$ of total funding in different accounting years. Kumar and Kandpal (2003) found that "The scale of work adopted by TBS is staggering..." showing that "... rejuvenation of traditional water harvesting structures on a wide scale is indeed possible". TBS-promoted work increased water availability in the region in agriculture-dominant and animal husbandry-dominant villages, resulting in significant economic gains, greater protection against ill-effects of drought and a marked reduction in distress migration (Kumar and Kandpal, 2003). Soil erosion also significantly reduced through measures including voluntary field bunding, and farmers were able to diversify cash crops and livestock composition due to assured water availability (Kumar and Kandpal, 2003).

A subsequent review by Jayanti (2009) found that 375 WHSs had been built over 25 years across the Arvari catchment, raising the water table and re-vegetating the landscape in a positively self-perpetuating dynamic. (It appears that WHSs and focal areas differed between studies.) Furthermore, whereas the Arvari River had been dry outside of the monsoon season in 1985, it ran perennially as a result of groundwater rehabilitation. Across Alwar district, more than 10,000 WHSs had been constructed between 1994 and 2008, restoring perennial flows to five other formerly seasonal rivers - the Bhagani-Teldehe, Arvari, Jahajwali, Sarsa and Ruparel benefitting 250 villages (Jayanti, 2009).

Glendenning and Vervoort (2010) recorded over 366 WHSs built in the Arvari catchment since 1985. They estimated potential recharge from seven WHSs, representing three different types and six landscape positions, through monitoring water level fluctuation in 29 dug wells. Average daily potential recharge from WHSs varied between 12 and $52 \mathrm{~mm} /$ day, while estimated actual recharge reaching groundwater ranged from 3 to $7 \mathrm{~mm} /$ day; soil storage, local groundwater mounding beneath structures and lateral transmissivity in the aquifer explain the difference. Overall, approximately $7 \%$ of rainfall recharged groundwater via WHSs in the catchment during both the comparatively wet and dry years of field analyses, with key differences between WHSs due to engineering design and location. These results indicate that recharge from WHSs affects the local groundwater table, and may also move laterally impacting surrounding areas. Some trade-offs were also drawn, for example with lower potential recharge downstream in catchments where WHSs retained monsoon flows upstream (Glendinning and Vervoort, 2010). However, lack of information available on aquifer characteristics, geology and soil type creates uncertainties. 
Agrawal (1996) tested TBS's approach and outcomes based on engineering data and the narratives of local people from 500 families in 36 affected villages. Agrawal noted that no hydrological calculations were conducted to assess volumes of storm run-off, flood flow and the amount of water needed by local people in WHS design, as typically required for a structured engineering approach. WHS design was instead based on instinct, deliberation and consensus within village committees, with some input of technical knowledge by TBS (such as alignment of johadi with fractures in underlying rock strata visible from inspection of local open wells to optimise aquifer recharge). Whilst largely illiterate, these people nevertheless demonstrated significant traditional knowledge, designing WHSs and maintaining them as a communal asset. Using rainfall data, addressing both amount and timing and assumed run-off coefficient, Agrawal (1996) determined that, to capture flow and promote infiltration, "...optimal Johad storage for these areas would be 1000-1500 $\mathrm{m}^{3} /$ hect. [of catchment area] which would raise annual average groundwater table by 20ft'. Comparing this 'ideal' with 166 community-engineered johadi in the Arvari catchment, Agrawal (1996) considered that 35 were too small, 49 were small, 61 were optimal (800-1200 $\left.\mathrm{m}^{3} \mathrm{ha}^{-1}\right), 16$ were superfluous and only five were excessive. This provides strong evidence that traditional knowledge routed through traditional consensual processes, unquantified in scientific or engineering terms, produced robust and appropriate designs. However, Agrawal's simplistic definitions of 'superfluous' and 'excessive' do not take account of the multiple functions and local needs for which WHSs are designed, addressing not just infiltration but also potentially surface water storage. Location-specific, consensual design may therefore have been even better tuned to multiple, local needs.

\subsubsection{Environmental outcomes}

TBS has worked with communities in over 1,068 villages in Alwar district, across an area of $6,500 \mathrm{~km}^{2}$, building over 8,600 WHSs by 2008 , resulting in shallow aquifer recharge bringing the water table from about 100-120 metres deep to 3-13 metres in dry seasons (Singh, 2009). Elevated water tables have had profound implications for catchment ecosystems. Rivers formerly running only during monsoon rains now hold water perennially within regenerated landscapes (Singh, 2009; Jayanti, 2009).

Perennial surface waters were observed in WHSs in the three case study catchments during field visits, their ecology and associated ecosystem services addressed by Everard (in preparation).

At wider landscape scale, Rathore (2003) reports increasing areas under forest in Thanagazi tehsil from $8.4 \%$ in $1989 / 90$ to $14.37 \%$ by $1998 / 99$, with agricultural area rising from $42 \%$ to $54.9 \%$. There is a convergence of interests between TBS and state interests in collective management of forest resources (Subramaniam, 2014).

Jayanti (2009) observed enhancement in grazing in the buffer zone adjacent to Sariska National Park, reducing grazing pressure in the Park's core zone. Paw prints of striped hyena were observed on the newly created Beechkharaga johad bank in March 2015, and villagers around this and other WHS reported that leopard, occasional tiger and other wildlife regularly descend from the Park to drink. 


\subsubsection{Economic outcomes}

Significant observed economic benefits resulting from groundwater recharge include food sufficiency and income from profitable farming due to ecosystem service enhancements from improved soil moisture and catchment hydrology. The area under single cropping and double cropping increased from $11 \%$ to $70 \%$ and from $3 \%$ to $50 \%$ respectively, improving significantly the livelihoods of farmers (Singh, 2009). Forest increased from $7 \%$ to $40 \%$ through agro-forestry and social forestry, providing sufficient fuel wood and sequestering atmospheric carbon (Singh, 2009).

TBS has succeeded in drawing upon wider funding, though insists on a minimum of $30 \%$ funding from local communities to assure communal ownership and continued maintenance. $90 \%$ of the efforts and financial resources routed through TBS were directed at water harvesting and conservation, including linked soil and forest conservation (Agrawal, 1996). 'Sweat equity', in the form of volunteer labour, or shramdan (a form of collective labour for local good closely linked to Gandhian ideals of self-sufficiency and mutual aid) is central to WHS construction and maintenance. These interventions have been economically efficient: some $62 \%$ of total funds received by TBS were spent directly on building WHSs and mobilising communities across Rajasthan, and $91 \%$ of total funds provided by SIDA were spent on community structures with only $9 \%$ spent on private structures (Kumar and Kandpal, 2003).

Agrawal (1996) compared the costs of water conservation work with their benefits. Community-based collaboration in WHS design and construction reduced costs, assessed as IN₹0.5-2 (US\$0.01-0.04) per $\mathrm{m}^{3}$ storage area. Strong correlation was observed between recharge capacity and groundwater rise, and between per capita increase in the value of the Gross Village Product and investment by villages in water conservation work with a ratio around 4:1 (Agrawal, 1996). The correlation between village investments in integrated water management was stronger for economic uplift than for groundwater rise alone, as regeneration of soil fertility and moisture, forests and grassland provided additional beneficial ecosystem services. Agrawal (1996) concluded that johadi "... are, by and large, engineering-wise sound and appropriate", concluding that "There can be no better rural investment than on Johads".

At village scale, distribution of benefits and shares of costs of WHS construction and management are key issues. Whereas common lands are grazed, croplands are privately-owned. Greater investment in WHSs is required through Gram Sabha by those most directly benefitting from cropland downstream and upstream of anicuts and from the benefits of well recharge (Kanhaiya, pers.comm.).

However, successive Five Year Economic Plans developed by central government still regard water as a commodity to be exploited "...in exactly the same way as any other resource" (Subramaniam, 2014). Whilst johadi are founded on systemic interconnections between water, forests and agriculture, siloed government ministries see only univalent economic optimisation and maximisation logics. Many local people even reject proposals for 'public-private partnerships' in resource management because past experience reveals asymmetric distributive benefits. 
Local controls, including appropriate pricing policies, are necessary to protect the rights of both small and large farmers, whilst creating incentives for local groundwater recharge solutions and enabling industry to operate (Damle, 2009).

\subsubsection{Political (governance) outcomes}

The TBS experience demonstrates that success often relies on governance based on renewed community-environment relations, which may entail challenge to statecentric neoliberalisation of water resources.

Hydrological recovery had triggered conflict between local communities and the state. As fisheries, like water, fall under central government control, once fish recolonised restored open waters in the Arvari catchment, the Rajasthan government issued a license in 1996 permitting fishing rights to a private contractor from outside the region (Singh, 2009; Sinha et al., 2013). State-issued rights were issued for IN₹18,700, although TBS believed the market value to exceed IN₹100,000 (Subramaniam, 2014). Harmeerpur residents resisted this take-over of resource rights, also recognising that central control of fisheries could be followed by centralised appropriation of the water resources regenerated by community efforts and likely to reignite the cycle of disempowerment, ecosystem degradation and socio-economic decline (Sinha et al., 2013). Village residents denied contractors access to the river, leading to conflict with the government department of fisheries and the contractor. The contractor reportedly put the pesticide Aldrin into the river to kill the fish, creating a dangerous situation not merely through risks of poisoning people and stock but as the presence of fish may contribute to the lack of incidences of malaria despite creation of new, substantial surface waters (Singh, 2009). Pressure on government led to annulment of the contract; no Government licence for fishing has since been granted in the Arvari. However, villagers adjacent to the Mandalwass upper impoundment (site MAu) in the Baghani catchment grant a commercial licence for fishing in order to provide income to maintain the dam.

TBS-brokered successes have had further positive impacts on State and National water policies including: formation of a national water network addressing issues of community water ownership; influencing state drought relief works refocusing on WHSs; contributing to the Sariska Tiger Reserve's Soil Conservation works; spreading learning to other states; and educating officers within Government (Kumar and Kandpal, 2003). Kumar and Kandpal (2003) observed that TBS was also active in policy advocacy for water management at Rajasthan State level, attempting to steer State Water Policy in a more equitable direction particularly through 'Jal Biradari' networks at nested scales from regional to state and national.

To promote more integrated management between villages sharing a common and connected groundwater and surface water resource, TBS leadership led to the 72 villages within the Arvari sub-catchment forming an Arvari Sansad (Arvari Parliament) to frame water use rules (Jayanti, 2009). This included localised restrictions on growing water-intensive crops such as paddy rice, instituting rotational pasture use, and limiting forest use to lopping branches for fuel or construction but not felling trees. The Arvari Sansad is one of several river parliaments based on catchment boundaries established under TBS leadership. 
Most TBS-initiated concrete anicuts are strictly illegal, as regulations require prior state Irrigation Department consent. Johadi and similar structures are also inherently illegal as the Rajasthan Drainage Act of 1956 specifies "Water resources standing collected either on private or public land (including groundwater) belong to the Government of Rajasthan". However, recognition of successes from village to higher political levels up to the President of India has ensured that notices issued by Rajasthan's Irrigation Department have not been enforced.

Reclamation of rights to commons from state or private agency control has become increasingly common amongst indigenous people across India (Fenelon, 2012; Subramaniam, 2014), resisting 'accumulation by dispossession' through commodification and privatization by state and corporate interests (Haugerud, 2010). NGOs have played significant roles in mobilising citizens and contributing to practices seeking local neoliberalism (Subramaniam, 2014).

\section{Discussion}

Organisation of knowledge deduced from field and literature sources around the STEEP framework demonstrates not only that multiple factors contribute to observed successes in regenerating the linked socio-ecological system, but also that systemic interconnections between these factors are essential if initiatives and their beneficial outcomes are to be accepted, implemented and maintained.

\subsection{Contribution and interactions between multiple factors}

Underpinning the cycle of regeneration is the recovery of catchment ecosystems, and particularly local cycling of water at village scale, to recover ecosystem service flows supporting social and economic outcomes. Central to this in arid landscapes is regeneration of groundwater and surface waters, providing a diversity of direct services (fresh water for domestic and agricultural uses) and indirect services ranging from soil regeneration, cycling of nutrients and water, carbon storage and favourable microclimate, as well as regeneration of wildlife and its associated societal meanings and uses (the latter addressed by Everard, in preparation).

However, there is a key axis between environmental and social restoration, TBS promoting re-establishment of traditional institutions, traditions and skills lost during India's early independence to achieve enduring, low-cost water harvesting outcomes. This is consistent with the Gandhian Jal Swara approach of linking the needs of people with the ecosystems that support them, learning to live within the carrying capacity of adjacent natural resources. Jayanti (2009) recognised this 'joining up' of interests as an adaptive approach to farm economy-based livelihoods, climate change resilience and population growth/food security, all sustained by better-functioning catchment and groundwater ecosystems.

The axis between environmental and social factors adapted to local conditions also depends on the innovation, or in this case the reinstitution, of appropriate technologies. A centralised 'dam and pipe' approach, often favoured by centralised 
governments, may enhance some services of benefit to more influential members of society, but often at net cost to local beneficiaries of many wider ecosystem services arising from water retention and movement through catchments (Everard and Kataria, 2010; Everard, 2013). Johadi and other WHS techniques promoting localscale recharge and adapted to expressed local needs offer a more distributed approach, contributing to restoration of multiple ecosystem services of substantial cumulative benefit to local people. The importance of using local perspectives and indigenous knowledge in the design process is endorsed by Agrawal (1996) when comparing johad areas with crudely modelled idealised criteria, suggesting that local deliberation accounted better for heterogeneous local needs, geographic and other considerations

The evidence provided in the Results section highlights that this localised approach can be highly economically efficient. Not only is it achieved at low cost through community participation, but significantly positive and enduring socio-economic outcomes for local people have resulted from enhancing ecosystem vitality and services.

Restoration of village-scale governance, inspiring and coordinating local involvement, deliberation and engagement with solutions of sustainable benefit, has been central to reversing a former cycle of socio-ecological degradation also observed more widely across the post-colonial developing world following statebrokered 'accumulation by dispossession' (Harvey, 2003). Reengagement of people with governance to achieve positive management of the ecosystems they inhabit is vital for water-vectored regeneration in arid and semi-arid landscapes. It is also essential that devolved consensual governance addresses not merely water recharge, but also measures to ensure its sustainable exploitation including zoning of land-use, modification of crop production and other uses better to integrate with environmental 'carrying capacity', and sustaining flows of ecosystem services supporting community livelihoods.

Governance has ultimately also to address potentially nested ramifications, biophysically and socially, within catchments. Successes in the case study catchments have rested on the progressive building of governance and connection of local solutions at nested scales, from village (Gram Sabha) to catchment (Arvari Sansad), and influencing State and National policy by positive example and through Jal Biradari, but always with community-scale activities as their foundation. Coherent nesting is essential to address the functioning of whole river ecosystems, whilst empowering local communities and making use of their context-specific knowledge about environmental conditions and needs.

As observed in the case of state allocation of fisheries, raising concerns that community-regenerated water resources could also be recaptured by state control, achievement of sustainable outcomes may at times entail confronting central government. This is consistent with the Gandhian ideal of challenging unjust laws through on-violent resistance. Though conflicts with the state and risks of incarceration have attended protests by TBS, the net outcomes has been greater respect from the state - from presidential to state level - including not merely explicit recognition of local successes but also the views of Jal Biradari. 


\subsection{Meta-level outcomes}

It is implicit in the behaviour of systems that emergent properties arise from system functioning. The observed cycle of socio-ecological regeneration is one such metalevel outcome. Associated with it is the empowerment of women, freed from the drudgery of traditional foraging for limited environmental resources - water, fodder and fuel wood - and able to participate in socially progressive activities such as traditional medicine, education (particularly of girls) and participation in governance. A further significant outcome of restored ecological, social governance conditions is an enhancement to the overall resilience of the socio-ecological system, as evidenced by Indian presidential commendation of the contribution of linked community-scale activism in water and catchment management to averting the more severe consequences of drought and distress migration observed elsewhere across India.

\subsection{Distinctive features of the TBS-promoted successes}

Recognition of the multi-beneficial restoration of traditional, local-scale groundwater recharge infrastructure in semi-arid and arid regions of India is not unique to TBS, for example with successive abandonment of tanks significant in aridification across southern India and their recovery recognised as vital for restoring hydrology and associated sustainability (Bardhan, 2000; Kajisa et al., 2004). However, TBS has been extraordinarily successful in promoting practical outcomes of demonstrable long-term benefit to ecosystems, community structure and socio-economic progress, as recognised to Indian presidential level and including numerous international donors and awards (including the 2015 Stockholm Water Prize: SIWI, 2015) and also increasing recognition that the Rashtriya Jal Biradari has an important role to play in addressing necessary legislative reforms with respect decentralisation of water management. Reform is certainly overdue, in India as indeed across much of the world and in respect of water and other societal challenges, with the state changing in attitude from controller to enabler of appropriate physical and societal infrastructure adapted to local geography and socio-economic needs (Elvidge, 2012).

Central to the TBS approach has been community-scale engagement in selfbeneficial solutions, both technically and in terms of economic and governance considerations. Often, this has relied on continuing funding of advice and support, though from an international donor perspective this low-level activity represents good value for money and may be attractive to state funding as government perspectives change from centralised control to supporting local collaborative solutions.

TBS successes have also stemmed from a learning approach, right from inception in listening to local perspectives about the need for water rather than education and the advice a lower-caste older lady to restore or create small, localised WHSs to recharge groundwater. This learning approach, including promotion of village-scale learning and deliberation on WHS design, financing and management, has continued, including into successive larger-scale (catchment and national) initiatives that make local activities more efficient in helping people meet their needs by 
protecting and enhancing the supportive ecosystem capacities of their host landwater ecosystems.

A learning approach has also led to co-creation and community adoption of consensual guiding principles supporting self-reliance, community-level engagement and co-management synergistically with the ecosystems that support wellbeing, in preference to rules imposed from outside. A similar empirical approach based on cross-regional observations led Ostrom (1990) to develop the underpinning principles of common pool resource (CPR) theory. CPR also focuses on community level co-management, representing post-modern scientific thinking and rejecting highly centralised natural resource governance as practised during the post-colonial era. There is a high degree of congruence between CPR principles and observed factors behind successes in the case study region, as also in semi-arid region of Spain where positive social capital supported beneficial groundwater management arrangements (Lopez-Gunn, 2012).

\subsection{Transferrable principles}

The STEEP-inspired stepwise approach in this discussion - (Environmental) recognising how ecosystem capacity can be protected or enhanced to provide necessary supportive ecosystem services; (Social) identification of social arrangements and recognition of potential benefits that can promote this; (Technological) development of novel or recognition of traditional technical innovations that can regenerate the land-water ecosystem; (Economic) creation of a cost-benefit case in terms of values (not necessarily financial) to all members of society; and (Political/governance) evolution of appropriate governance mechanisms that may also entail resisting centralised government restrictions - effectively constitutes a logical, ecosystem-based approach for exploring sustainable development of water resources in other regions subject to cycles of degradation.

Some major water-consumptive industries have sought to replicate groundwater infiltration technologies at industrial scale to replenish resources to match factory demand in Rajasthan (Confederation of Indian Industry, n.d.). Singh (pers. comm.) expresses discomfort with this approach, perceiving it as undermining resources underpinning traditional livelihoods based on sufficiency and self-reliance. However, accepting industrialisation as inevitable, the experiment of adapting traditional, localscale groundwater regeneration techniques to industrial scale has virtue, though must be carefully monitored to assess its viability as a sustainable alternative to heavy-engineering water management approaches within a mix of livelihoods. It is important that exploration and innovation is adapted to local geographical, cultural and climatic conditions if it is to be sustainable, accepted, and potentially to rebuild degraded ecosystem capacity for wider societal benefit.

\section{Conclusions}

- STEEP provides a useful framework for exploring the contributions and interactions of linked factors in analysis of complex socio-ecological systems. 
- Multiple, complex and interdependent factors were entailed in restoring community-based groundwater recharge in target catchments.

- Increasing ecosystem service capacity within degraded semi-arid catchments provides a basis for enhancing life prospects of local people, but depends upon restoration of effective local decision-making and governance.

- Traditional and innovative techniques for ecosystem restoration need to take account of geographic and cultural factors, flexibly addressing real needs and making use of indigenous knowledge.

- Governance must address both enhancement of carrying capacity and resource exploitation, and be nested to optimise resource efficiency at local scales.

- A better-functioning ecosystem enhances the resilience of ecology as well as socio-economic wellbeing, with a range of peripheral benefits including potential empowerment of women.

- Addressing the different dimensions of STEEP and interactions between them can potentially provide a transferrable, ecosystem-based approach to reversing cycles of degradation in arid and semi-arid, groundwater-dependent regions.

\section{Acknowledgements}

Many thanks to Rajendra Singh, Abhinav Agrawal, Kanhaiya Lal, Gopal Singh, Maulik Sisodia and Suresh Raikwar of Tarun Bharat Sangh for their hospitality, time and knowledge, and also Rudhmalmena, the headman of Harmeerpur. Also to Rakesh Vaish for transport, translation and explanation of local contexts. Elements of fieldwork were supported with core funding from the University of the West of England (UWE), supported by Professor Jackie Rogers. Professor Chad Staddon (UWE) provided helpful comments, and Dr Jackie Vale assisted with planimeter measurements.

\section{References}

Agrawal GD 1996 An engineer's evaluation of water conservation efforts of Tarun Bharat Sangh in 36 villages of Alwar District. Tarun Bharat Sangh, Alwar

Agarwal A and Narain S eds 1997 Dying wisdom: Rise, fall and potential of India's traditional water harvesting systems. New Delhi: Centre for Science and Environment

Aretano R, Petrosillo I, Zaccarelli N, Semeraro T and Zurlini G 2013 People perception of landscape change effects on ecosystem services in small Mediterranean islands: A combination of subjective and objective assessments Landscape and Urban Planning 112 63-73

Aureli A and Ganoulis J 2005 The UNESCO project on internationally shared aquifer resources management (UNESCO/ISARM): overview and recent developments. In: Stournaras et al. (eds.) Proceedings of the 7th Hellenic Hydrogeological Conference Vol II Hellenic Chapter of IAH, Athens 35-46

Bardhan P 2000 Irrigation and cooperation: an empirical analysis of 48 irrigation communities in South India Economic Development and Cultural Change 48(4) 84765 
Birch S 2012 Springing the poverty trap. Green Futures Special Edition: Shared Future - how co-operatives can reboot a sustainable economy, February 2012, 8-11

Birkenholtz T 2009 Groundwater Governmentality: Hegemony and Technologies of Resistance in Rajasthan's (India) Groundwater Governance The Geographical Journal 175(3) 208-220

Budds J and McGranahan G 2003 Are the debates on water privatization missing the point? Experiences from Africa, Asia and Latin America Environment and Urbanization 15(2) 87-113

Central Ground Water Board 2006 Dynamic Ground Water Resources of India. New Delhi

Cochran J and Ray I 2009 Equity Re-examined: A Study of Community-Based Rainwater Harvesting in Rajasthan, India. World Development 37(2) 435-444

Confederation of Indian Industry Not dated Breaking the Boundaries in Water Management: A Case Study Compendium. Confederation of Indian Industry Northern Region, Jaipur.

Damle V 2009 Sectoral Allocation and Pricing of Groundwater. Bhu-Jal News Quarterly Journal 24(4) 57-68

Downing RA 2002 Groundwater: our hidden asset British Geological Survey, Nottingham, UK

Down to Earth 1999a To hell and back. Down to Earth, $15^{\text {th }}$ March 1999 (http://www.downtoearth.org.in/node/19488, accessed $3^{\text {rd }}$ September 2014)

Down to Earth 1999b Coming back to life. Down to Earth, $15^{\text {th }}$ March 1999 (http://www.downtoearth.org.in/node/19493, accessed $3^{\text {rd }}$ September 2014)

Eckstein Y and Eckstein G 2005 Transboundary aquifers: conceptual models for development of international law Groundwater 43 679-90

Elvidge J 2012 The Enabling State - A Discussion Paper Carnegie UK Trust

Everard M 2013 The Hydropolitics of Dams: Engineering or Ecosystems? Zed Books, London

Everard $\mathbf{M}$ in preparation Community-based groundwater and ecosystem restoration in semi-arid north Rajasthan (2): recovery of cultural meaning and value

Everard M, Harrington R and McInnes RJ 2012 Facilitating implementation of landscape-scale integrated water management: the integrated constructed wetland concept Ecosystem Services 2 27-37

Everard M and Kataria G 2010 The proposed Pancheshwar Dam, India/Nepal: A preliminary ecosystem services assessment of likely outcomes. IES research report. (http://www.ies-uk.org.uk/resources/papers/pancheshwar dam report.pdf, accessed $01^{\text {st }}$ October 2015)

Famiglietti JS 2014 The global groundwater crisis Nature Climate Change 4 945948

Fenelon JV 2012 Indigenous peoples, globalization and autonomy in world-system analysis. In: Babones SJ and Chase-Dunn C (eds) Routledge Handbook of WorldSystems Analysis. New York: Routledge 304-312 
Gandhi MK 1947 Hind Swaraj. G A Natesan and Co, Madras

Glendinning $\mathbf{C J}$ and Vervoort RW 2010 Hydrological impacts of rainwater harvesting $(\mathrm{RWH})$ in a case study catchment: The Arvari River, Rajasthan, India. Part 1: Field-scale impacts Agricultural Water Management 98(2) 331-342

Glennon R 2002 Water Follies: Groundwater Pumping and the Fate of America's Fresh Waters. Island Press

Government of India 2007 Report of the expert group on "Groundwater management and ownership" submitted to Planning Commission, September 2007. Government of India, Planning Commission, Yojana Bhavan, Parliamentary Street, New Delhi

Gupta S 2011 Demystifying 'tradition': The politics of rainwater harvesting in rural Rajasthan, India Water Alternatives 4(3) 347-364

Harvey D 2003 The New Imperialism. Oxford: Oxford University Press

Haugerud A 2010 Neoliberalism, satirical protest, and the 2004 U.S. presidential campaign. In: Greenhouse C (ed.) Ethnographies of Neoliberalism. Philadelphia: University of Pennsylvania Press 112-127

Hills ES ed 1966 Arid Lands: A Geographical Appraisal. Methuen Young Books.

Jha BM and Sinha SK 2009 Towards Better Management of Ground Water Resources in India Bhu-Jal News Quarterly Journal 24(4) 1-20

Jayanti G 200925 years of evolution: restoring life and hope to a barren land Tarun Bharat Sangh, Alwar

Kajisa K, Palanisami K and Sakurai T 2004 Declines in the collective management of tank irrigation and their impacts on income distribution and poverty in Tamil Nadu, India. FASID Discussion Paper Series on International Development Strategies, No. 2004-08-005, Tokyo, Foundation for Advanced Studies on International Development

Kumar MD 2003 Food security and sustainable agriculture in India: The water management challenge International Water Management Institute, Working Paper 60. Columbo, Sri Lanka: International Water Management Institute

Kumar P and Kandpal BM 2003 Project on Reviving and Constructing Small Water Harvesting Systems in Rajasthan. Sida Evaluation 03/40, Swedish International Development Cooperation Agency. Stockholm

Lopez-Gunn E 2012 Groundwater governance and social capital Geoforum 43(6) 1140-1151

Mateljan S 2007 Water wars: preventing and resolving conflicts over transboundary groundwater resources Murdoch University E Law Journal 14 178-214

Mishra A 1995 The Radiant Raindrops of Rajasthan New Delhi: Gandhi Peace Foundation

Mishra A 1997 Even today these small reservoirs are full of water (a book in Hindi). New Delhi: Gandhi Peace Foundation

Moench M 1994 Approaches to Groundwater Management: To Control or Enable? Economic and Political Weekly 36(11) A135-A146 
Morrison J and Wilson I 1996 The Strategic Management Response to the Challenge of Global Change," in Future Vision, Ideas, Insights, and Strategies, $\mathrm{H}$. Didsbury, Ed. Bethesda, Md.: The World Future Society, Maryland, USA

Ostrom E 1990 Governing the commons: The evolution of institutions for collective action Cambridge, UK: Cambridge University Press

Pangare G 2003 Tarun Bharat Sangh : Evaluation report. Utrecht, the Netherlands: Interchurch Organisation for Development Cooperation (ICCO)

Pearce F 2004 Keepers of the Spring: Reclaiming Our Water in an Age of Globalization. Island Press, Washington DC.

Postel S 1999 Pillar of sand: Can the irrigation miracle last? New York, USA: W. W. Norton \& Company

Pandey DN, Gupta AK and Anderson DM 2003 Rainwater harvesting as an adaptation to climate change Current Science 85(1) 46-59

Rathore MS 2003 Community based management of ground water resources: a case study of Arwari River basin Institute of Development Studies, Jaipur

Rathore MS 2005 Groundwater exploration and augmentation efforts in Rajasthan: a review Institute of Development Studies, Jaipur

Seckler D, Barker R and Amarasinghe U 1999 Water Scarcity in the Twenty-first Century. Water Resources Development 15 (1/2): 29-42

Sharma BK, Kulshreshtha S and Sharma S 2013 Historical, sociocultural, and mythological aspects of faunal conservation in Rajasthan. In: Sharma, B.K.,

Kulshreshtha, S. AND Rahmani, A.R. (eds.) Faunal Heritage of Rajasthan, India: general Background and Ecology of Vertebrates, Volume 1. Springer: New York.

Singh DK and Singh AK 2002 Groundwater Situation in India: Problems and Perspective International Journal of Water Resources Development 18 563-580

Singh R 2009 Community Driven Approach for Artificial Recharge -TBS Experience Bhu-Jal News Quarterly Journal 24(4) 53-56

Sinha J, Sinha MK and Adapa UR 2013. Flow - River Rejuvenation in India: Impact of Tarun Bharat Sangh's Work. SIDA Decentralised Evaluation 2013:28. Swedish International Development Cooperation Agency, Stockholm.

SIWI 2015 The water man of India wins 2015 Stockholm Water Prize (http://www.siwi.org/prizes/stockholmwaterprize/laureates/2015-2/, accessed $1^{\text {st }}$ October 2015)

Staddon C 2010 Managing Europe's Water Resources: $20^{\text {th }}$ century challenges Ashgate.

Steward WC, Kuska S 2011 Sustainometrics: Measuring Sustainability, Design, Planning and Public Administration for Sustainable Living Greenway Communications

Subramaniam M 2014 Neoliberalism and water rights: The case of India Current Sociology 64(2) 393-411

The Hindu 2000 Hope in the midst of loss The Hindu $25^{\text {th }}$ June 2000 (http://www.thehindu.com/thehindu/2000/06/25/stories/1325041a.htm accessed 01st October 2015.) 
United Nations 2003 Water for people, water for life World Water Assessment Programme, United Nations General Assembly

Vaidyanathan A 1996 Depletion of Groundwater: Some Issues Indian Journal of Agricultural Economics 51(1-2) 184-92

Wani SP, Pathak P, Sreedevi TK, Singh, HP and Singh P 2003 Efficient Management of Rainwater for Increased Crop Productivity and Groundwater Recharge in Asia. CAB International 2003. Water Productivity in Agriculture: Limits and Opportunities for Improvement. (eds. W. Kijne, R. Barker and D. Molden) pp. 199-215.

Wani SP and Ramakrishna YS 2005 Sustainable Management of Rainwater through Integrated Watershed Approach for Improved livelihoods. In: "Watershed Management Challenges: Improved Productivity, Resources and Livelihoods", (eds. Bharat R Sharma, J S Samra, CA Scot and Suhas P Wani), IMMI Sri Lanka. pp39-60

Wani SP, Ramakrishna YS, Sreedevi TK, Long TD, Wangkahart T, Shiferaw B, Pathak P and Keshava Rao AVR 2006 Issues, Concept, Approaches Practices in the Integrated Watershed Management: Experience and lessons from Asia. In: Integrated Management of Watershed for Agricultural Diversification and Sustainable Livelihoods in Eastern and Central Africa: Lessons and Experiences from Semi-Arid South Asia. Proceedings of the International Workshop held during 6-7 December 2004 at Nairobi, Kenya, pp17-36

Wani SP, Sudi R and Pathak P 2009 Sustainable Groundwater Development through Integrated Watershed Management for Food Security Bhu-Jal News Quarterly Journal 24(4), 38-52

Woodward RT and Wui YS 2001 The economic value of wetland services: a metaanalysis Ecological Economics 37(2) 257-270 